\title{
Danuta Konieczka-Śliwińska
}

(Poznań)

\section{Region historyczny w historiografi, dydaktyce historii i edukacji szkolnej. Przegląd stanowisk i propozycji delimitacji}

$*$

$\int$

edną z podstawowych funkcji refleksji historyczno-dydaktycznej, jak pisał Jerzy Maternicki, jest „tworzenie pomostów pomiędzy nauką historyczną a społeczeństwem" ${ }^{1}$. Korzystając z dorobku i metod badawczych innych dyscyplin humanistycznych, dydaktyka historii dokonuje na potrzeby szeroko rozumianej edukacji historycznej specyficznego rodzaju adaptacji wybranych osiągnięć teoretycznych z takich dziedzin, między innymi, jak metodologia historii czy historia historiografii. Tworzy w ten sposób niezbędne zaplecze w postaci studiów teoretycznych dla działań praktycznych, podejmowanych przez nauczycieli w ramach procesu dydaktycznego. Zależność w tym przypadku wydawać by się mogła oczywista: im pilniej śledzą dydaktycy historii rozważania historyków nad wybranym problemem, tym szybciej do praktyki szkolnej mają szansę przeniknąć najnowsze osiągnięcia nauki historycznej. W rzeczywistości jednak transmisja teorii do praktyki nie jest procesem ani tak prostym, ani krótkotrwałym, a w obliczu konieczności pogodzenia wielu odmiennych propozycji definicyjnych z potrzebą jednoznacznych rozwiązań, dających się zastosować w codziennej pracy z uczniem

${ }^{1}$ J. Maternicki, Dydaktyka historii, [w:] Wspótczesna dydaktyka historii. Zarys encyklopedyczny dla nauczycieli i studentów, red. J. Maternicki, Warszawa 2004, s. 45. 
- często bywa także bardzo trudna, a czasem wręcz niemożliwa. Niniejszy tekst stanowi próbę prześledzenia przenikania się wspomnianych osiagnnięć teoretycznych w trzech powiązanych ze sobą obszarach: historiografii, dydaktyce historii i edukacji szkolnej, na przykładzie rozważań dotyczących sposobu rozumienia pojęcia „region historyczny” i kryteriów jego wyodrębniania (delimitacji).

Początki dyskusji wokół definicji „region historyczny” sięgają pierwszych lat okresu międzywojennego, kiedy to bardzo wyraźnie zarówno w obrębie ruchu regionalnego, jak i w środowisku naukowym ujawniła się potrzeba dookreślenia podstawowej kategorii, którą posługiwano się w badaniach regionalnych oraz w różnych formach popularyzacji historii regionalnej. Pomimo dużej rozbieżności poszczególnych stanowisk, można było wówczas zaobserwować zgodność w dwóch podstawowych kwestiach: po pierwsze, region jako pewna całość (społeczna, kulturalna, gospodarcza itp.) był stale odnoszony do całości wyższego rzędu wyodrębnionej w granicach państwa, po drugie, regiony należało wyodrębniać na podstawie zespołu różnych kryteriów, z których żadne nie jest wskazywane jako najważniejsze ${ }^{2}$. Warto jednak zauważyć, że dla poszczególnych środowisk zainteresowanie regionem historycznym miało w pewnym zakresie odmienne znaczenie: regionaliści, zaangażowani w działalność organizacyjną, w mniejszym stopniu byli skoncentrowani na określeniu dokładnych granic i kryteriów wyodrębniania poszczególnych regionów, akcentując przede wszystkim przywiązanie do „małej ojczyzny”, gdy tymczasem dla historyków zajmujących się badaniami nad historią regionalną odpowiedź na pytanie, czym są regiony historyczne, a w konsekwencji także przyjęcie w miarę jednoznacznych reguł delimitacji tych regionów, odgrywała decydującą rolę. Ostatecznie całość dyskusji nad regionem historycznym, zarówno w okresie międzywojennym, jak i po II wojnie światowej potoczyła się w dwóch kierunkach refleksji. Część badaczy koncentrowała się przede wszystkim na istocie i zasadzie delimitacji regionu historycznego, oczekując rozstrzygnięcia mającego istotne znaczenie dla praktyki badań regionalnych. Uważali oni bowiem, że najważniejsze dla regionalizacji historycznej jest określenie, jakie podziały natury administracyjnej należy przyjąć za podstawę wyodrębnienia danego terytorium. Z czasem wyłoniła się druga grupa historyków, którzy - przełamując to podsta-

2 Patrz m.in.: P. Kwiatkowski, Ideologia regionalizmu w Polsce międzywojennej, „Kultura i Społeczeństwo", T. XXVII, 1984, nr 4, s. 150. 
wowe założenie - szukali także innych kryteriów podziału na regiony. Ich zdaniem zarówno historyczne, jak i współczesne podziały administracyjne, nie mogły stanowić jedynego (czy też najważniejszego) czynnika warunkującego regionalizację historyczną.

Kłopot z ustaleniem kryteriów delimitacji regionów historycznych wynikał jednak nie tylko z naukowej przekory i ścierania się wielu koncepcji, ale dodatkowo komplikował się z powodu dużej niestabilności granic tych regionów. Jak pisał m.in. Andrzej Wyrobisz, regiony historyczne ulegają dość szybkim i częstym przeobrażeniom:

Podlasie oznaczało zupełnie inny region w XVI-XVIII w., inny zaś w XIX-XX w. Zasięg historycznej Małopolski niejako skurczył się po rozbiorach, kiedy to nazwę tę zaczęto stosować tylko do tej jej części, która znalazła się pod zaborem austriackim, wyłączając jej część północną pozostającą w granicach Królestwa Polskiego pod władzą Rosji. Powszechnie używane obecnie pojęcie „Kielecczyzna” nie istniało przed XIX w. ${ }^{3}$

Kluczowym problemem zatem pozostawał wybór jednego lub wielu kryteriów, które na tyle byłyby „pojemne” (optymalne), że pozwoliły by opracować regionalizację historyczną, uwzględniającą całość ziem polskich, nie tylko w wymiarze przestrzennym (czyli wszystkie tereny, które w danym momencie odpowiadają definicji regionu historycznego), ale także czasowym, tzn. w różnych okresach przeszłości tworzyły region historyczny.

Wśród historyków okresu międzywojennego największe uznanie zdobyła koncepcja oparcia badań regionalnych na podstawach geograficznych. Takie stanowisko reprezentował m.in. Stanisław Arnold, kiedy to w 1925 r. na łamach miesięcznika „Ziemia” stwierdził, że podstawą wyodrębnienia regionów są procesy geograficzno-historyczne ${ }^{4}$, podobnie jak Włodzimierz Antoniewicz, który w swoim artykule z 1933 r. przedstawił własną propozycję podziału regionalnego państwa polskiego na 33 krainy geograficzne 5 . Do zwolenników przyjęcia geograficznych kryteriów delimitacji regionów histo-

3 A. Wyrobisz, Historyczne badania regionalistyczne, [w:] Regionalizm a historia. Materiaty IV Krajowego Forum Regionalistycznego, Staszów-Sandomierz 25-27 września 1997 r., red. M. A. Zarębski, Staszów 1998, s. 38.

4 S. Arnold, Historia a regionalizm, "Ziemia”, R. X, 1925, s. 9.

5 A. Stępnik, Historia regionalna i lokalna w Polsce 1918-1939. Badania i popularyzacja, Warszawa 1990, s. 25-31. 
rycznych zaliczyć można w tamtym okresie również Karola Buczka, który przy pewnych zastrzeżeniach dopuszczał traktowanie jednostek geograficznych jako płaszczyzny odniesienia w historycznych badaniach regionalnych ${ }^{6}$. Jego wypowiedź z 1935 roku, będąca reakcją na artykuł Ewy Maleczyńskiej, dotyczący regionalizmu w nauczaniu historii, odegrała jednak szczególną rolę w dyskusji nie tyle nad delimitacją regionu historycznego, co w większym stopniu nad ogólnym rozumieniem tego pojęcia. K. Buczek był wówczas zdania, że podział regionalny ówczesnej Polski należało rozpatrywać w sferze idei, a nie faktów konkretnych. Za region historyczny uznawał bowiem jednostki terytorialne, które $w$ danej epoce posiadaty $w$ mniejszym lub większym stopniu własna historię ${ }^{7}$ W dziejach państwa polskiego, jego zdaniem, regiony historyczne, jeśli istniały, to jedynie do roku 1772 (czyli I rozbioru Polski) i nie pozostawily po sobie na tyle pozytywnych śladów, by do nich się odwoływać z punktu widzenia wychowania państwowego i narodowego. Do historii regionalnej należało więc nawiązywać tylko tam, gdzie rzeczywiście mieliśmy do czynienia z regionami historycznymi, czyli np. na Śląsku. W odniesieniu do innych terenów II Rzeczypospolitej można było, jak twierdził, odwoływać się jedynie do przedrozbiorowych regionów historycznych lub czekać na wytworzenie się nowego podziału regionalnego państwa ${ }^{8}$.

$\mathrm{Z}$ innych znaczących stanowisk historyków okresu międzywojennego w sprawie rozgraniczenia regionów warto przywołać jeszcze propozycje Bogdana Domańskiego (uwzględnienia takich kryteriów, jak warunki geograficzno-przyrodnicze, tradycja historyczna, podział administracyjny i warunki gospodarcze) $)^{9}$, a także Pawła Musioła, który z kolei wyodrębnił stałe (jak np. nazwa, przeszłość, tradycja wspólnoty plemiennej, administracja) oraz zmienne (np. gwara, kultura ludowa, struktura społeczno-gospodarcza) elementy składowe regionu historycznego ${ }^{10}$. Niejako zapowiedzią późniejszej (głównie w latach 70. XX wieku) zmiany kierunku tej dyskusji stał się artykuł Adama Próchnika, opublikowany w 1938 r. na łamach „Samorzą-

${ }^{6}$ K. Buczek, Zagadnienie regionalizmu $w$ nauczaniu historii w szkole średniej, [w:] Pamiętnik VI Powszechnego Zjazdu Historyków Polskich w Wilnie, 17-20 września 1935 r. T. I. Referaty, przygotował do druku F. Pohorecki, Lwów 1935, s. 544.

7 Ibidem, s. 543-544.

8 Ibidem, s. 544.

9 Por.: B. Domański, Zagadnienie kształtowania się regionów, „Ziemia Wołyńska”, R. 1, 1938, nr 1, s. 3.

10 Por.: P. Musioł, Zagadnienie regionalizmu na Śląsku, „Zaranie Śląskie”, R. XI, 1935, z. 2 , s. 88 . 
du Miejskiego", w którym stwierdził, że granice poszczególnych regionów historycznych nie pokrywają się z granicami administracyjnymi ${ }^{11}$. Uważał również, że kryterium rozgraniczenia regionów mogą stanowić szeroko rozumiane: granice historycznego współżycia i ciążenia danego środowiska i jego okolic; granice kulturalnego oddziaływania owego środowiska w chwili obecnej oraz granice najbliższych regionów historycznych ${ }^{12}$.

Pierwszymi historykami po II wojnie światowej, którzy w swoich rozważaniach nad regionem historycznym zwrócili uwagę nie na jedno, decydujące kryterium jego wyróżnienia, tylko na zespół kilku wiążących się ze sobą cech, byli Helena Madurowicz i Antoni Podraza. Ich badania z lat 50 . XX wieku odnosiły się jednak nie tyle do samej regionalizacji historycznej, co historyczno-gospodarczej, a tym samym koncentrowali się oni na definicji regionu historyczno-gospodarczego. Podejmując próbę regionalizacji gospodarczej Małopolski w drugiej połowie XVIII wieku, za czynniki regionotwórcze przyjęli: stosunki społeczne, specjalizację produkcji, środowisko geograficzne, strukturę demograficzną ${ }^{13}$. Jak ocenia Andrzej Wyrobisz, Madurowicz i Podraza, próbując dokładnie zdefiniować naukowo region historyczny i położyć kres dowolności stosowania tego pojęcia przez historyków regionalistów, nie wywołali jednak swoją propozycją szerszej dyskusji w tamtych latach ${ }^{14}$. Moim zdaniem większy wpływ na podstawy metodologiczne regionalizacji historycznej wywarły późniejsze rozważania Heleny Madurowicz-Urbańskiej nad regionem gospodarczym w przeszłości. Wychodząc bowiem od założenia, że podstawową przesłankę metodologiczną dla wyodrębniania regionów historycznych stanowi między innymi relacja człowiek (społeczeństwo)-środowisko (geograficzne, przyrodnicze) i związana z tym funkcja przestrzeni, postawiła ona tezę, że przy rozważaniu problemów przestrzeni w badaniach historycznych (a takim problemem jest właśnie dyskusja nad definicją regionu historycznego) konieczna jest zmiana w podejściu do przestrzeni jako takiej (w ogóle), zarówno jako przedmiotu, jak i narzędzia badania, i odwołanie się do ogólnej teorii przestrzeni oraz do osiagnnięć

11 A. Próchnik, Samorząd a zagadnienie historii regionalnej, „Samorząd Miejski”, R. XVIII, 1938, nr 9, s. 662-673.

12 Ibidem, s. 667.

${ }^{13}$ H. Madurowicz, A. Podraza, Regiony gospodarcze Matopolski Zachodniej w drugiej połowie XVIII wieku, Wrocław-Kraków-Warszawa 1958, s. 10 i 21.

${ }^{14}$ A. Wyrobisz, op. cit., s. 42. 
innych nauk szczegółowych, np. geografii ${ }^{15}$. W ten sposób H. Madurowicz-Urbańska zwróciła uwagę na fakt, iż, definiując region historyczny, powinniśmy spojrzeć na niego szerzej i po pierwsze: skupić się na wyłonieniu zespołu cech go charakteryzujących, po drugie - istotne w tych rozważaniach mogą być ustalenia geografów. Na podkreślenie zasługuje również i to, że H. Madurowicz-Urbańska w swoich badaniach była niezwykle precyzyjna, w tekstach zawarła szereg ustaleń definicyjnych, uporządkowanych i opisanych we wzajemnych relacjach, przez co łatwiej było zrozumieć jej tok myślenia i odnieść się do poczynionych ustaleń.

Mniej więcej w tym samym czasie propozycję rozwiązania problemu delimitacji regionów historycznych przedstawiła również Ewa Maleczyńska na łamach „Śląskiego Kwartalnika Historycznego Sobótka”'16. Jej zdaniem za podstawę badań regionalnych (także i historycznych) należało przyjąć współczesne podziały administracyjne. Co ważne, zdawała sobie sprawę z ograniczeń, jakie niesie to założenie i że może ono znaleźć zastosowanie przede wszystkim w pracach popularyzatorskich, dociekaniach podejmowanych przez badaczy lokalnych oraz w większości prac badawczych historyków zawodowych, zajmujących się historią regionalną. Natomiast w monografiach naukowych, dotyczących określonej przestrzeni czasu, kiedy istniały podziały polityczno-administracyjne różne od tych współczesnych, trzeba było jak pisała Maleczyńska: zachować historyczny, a nie aktualnoadministracyjny zasięg terytorialny badań. Przyjęcie „narastającej teraźniejszości” jako umownego punktu odniesienia do poszukiwań regionalnych i lokalnych w przeważającej jednak części badań historycznych, było w Jej mniemaniu zabiegiem „najbardziej czytelnym i umotywowanym” ${ }^{17}$.

Kilka lat później odmienne stanowisko w sprawie regionalizacji historycznej zajął ponownie Karol Buczek, publikując artykuł na łamach „Małopolskich Studiów Historycznych”, w którym złagodził nieco swoje wcześniejsze poglądy na temat regionów historycznych. To właśnie w tym tekście stwierdził, że niewiele chyba mamy naukowych terminów, używanych równie

15 H. Madurowicz-Urbańska, Metodologiczne i metodyczne aspekty regionalizacji historyczno-gospodarczej. (zagadnienia wstępne), „Historyka”, T. V, 1975, s. 49-51.

16 E. Maleczyńska, W sprawie badań nad historia lokalna, „Śląski Kwartalnik Historyczny - Sobótka”, 1960, nr 3, s. 331-354.

17 Ibidem, s. 341. 
beztrosko i dowolnie, jako stowo "region” i jego pochodne ${ }^{18}$. Choć nie sformułował jednoznacznej definicji regionu historycznego, to jednak przedstawił cały szereg założeń, które kolejni badacze uwzględniali w swoich rozważaniach. Punktem wyjścia do swojej refleksji nad regionami historycznymi Karol Buczek uczynił pojęcie regionu, który rozumiał jako

każdy większy lub mniejszy obszar, który różni się od innych jakąś określoną właściwością czy określonymi własnościami, albo przynajmniej swoim położeniem, np. nad jakąś rzeką lub wokół jakiegoś znaczniejszego ośrodka miejskiego ${ }^{19}$.

Historyk, jego zdaniem, zajmując się regionalizacją historyczną i szukając czynników, pozwalających określić dany obszar jako region historyczny, nie powinien przyjmować za jego podstawę (kryterium) elementów geograficznych, lecz kwestie społeczne, wysuwając na plan pierwszy człowieka. Region historyczny Buczek opisał ogólnie jako twór pośredni między państwem i osiedlem, ponieważ stanowi zarówno część terytorium państwa w jego historycznych granicach, jak również obejmuje grupę („sumę”) osiedli, które z kolei łączą w sobie jeszcze mniejsze jednostki (,jakiś obszar”) ${ }^{20}$. Sformułowanie bardziej szczegółowej definicji, zdaniem K. Buczka, nie było możliwe, ze względu na zbyt dużą różnorodność tych tworów, zarówno pod względem wielkości, jak i charakteru. Na potrzeby praktycznych badań historycznych proponował, by regiony historyczne pokrywały się z istniejącymi w badanym okresie (a nie współcześnie) jednostkami terytorialnej organizacji państwowej. Uważał, że jest to niezbędny warunek naukowego poznania, ponieważ regiony historyczne powinny odtwarzać „istniejącą obiektywnie rzeczywistość historyczną"21. Swoje rozważania argumentował tym, że zmiany terytorialnej organizacji państwowej towarzyszą zmianom w regionalizacji historycznej i wtłaczanie np. badań nad Polską w XVIII wieku do istniejącego współcześnie podziału na województwa jest zupełnie nieprzydatne. Aby w pełni uchwycić historyczną zmienność granic regionów, K. Buczek wprowadził rozbudowaną klasyfikację regionów historycznych, odwołując

${ }^{18}$ K. Buczek, O regionach historycznych, „Małopolskie Studia Historyczne”, R. VI, 1964 , z. 3/4, s. 144 .

19 Ibidem, s. 144.

${ }^{20}$ Ibidem, s. 147.

${ }^{21}$ Ibidem. 
się do różnych kryteriów ich podziału (polityczno-administracyjnych, społecznych, geograficznych). W ten sposób podzielił je na samodzielne regiony, czyli obdarzone własną osobowością ustrojową oraz posiadające własną historię, oraz historyczne regiony niesamodzielne, nieposiadające takiej osobowości ustrojowej. Dodatkowo w obrębie tych dwóch kategorii wyróżnił regiony wyższorzędne, średnio- i niższorzędne. Zwrócił również uwagę na trzy inne rodzaje regionów: historyczne regiony specjalne, regiony reliktowe i regiony geograficzno-historyczne, traktowane jako regiony historyczne niewłaściwe. Za regiony właściwe bowiem należy uznać jedynie te, które były $w$ badanym okresie samodzielnymi lub niesamodzielnymi jednostkami organizacji terytorialnej, przede wszystko polityczno-administracyjnej, a także „specjalnej" (kościelnej, majatkowej itd.) $)^{22}$.

Pomimo rozbudowanej propozycji wydzielania regionów historycznych stanowisko Karola Buczka spotkało się jednak z krytyką. Z punktu widzenia praktycznych badań regionalnych, a zwłaszcza w przypadku dużych syntez regionalnych czy monografii przedstawiających całość dziejów od czasów najdawniejszych do współczesności, przyjęcie koncepcji Buczka skutkowałoby, jak pisał m.in. Zenon Guldon, opracowaniem dla poszczególnych okresów obrazu dziejów zupełnie odmiennych terytoriów ${ }^{23}$. W tej sytuacji łatwiejsze w wielu przypadkach okazało się zastosowanie współczesnych kryteriów administracyjnych, co proponowała wcześniej Ewa Maleczyńska. Podobny pogląd w tej sprawie wyraził w latach 70. znany historyk Gerard Labuda. Uznał on przede wszystkim, że „wnikliwą i bardzo instruktywną” propozycję K. Buczka ogranicza klauzula „w badanym okresie”, co nie daje się pogodzić z coraz częstszą praktyką badania całości dziejów danego terytorium na przestrzeni wieków. Odwołując się do ustaleń E. Maleczyńskiej, Labuda uznał, że konieczne jest przyjęcie współczesnych podziałów administracyjnych nie tyle za podstawę, co za punkt wyjścia historycznych badań regionalnych ${ }^{24}$.

Dyskusję nad regionem historycznym znacznie ożywił na przełomie lat sześćdziesiątych i siedemdziesiątych poznański historyk Jerzy Topolski, nadając jej zupełnie nowy kierunek. Uważał przede wszystkim, że zdefinio-

22 Ibidem, s. 148-150.

23 Z. Guldon, Kilka uwag o historii regionalnej i lokalnej, [w:] Pamiętnik XIV Powszechnego Zjazdu Historyków Polskich, t. 2, red. D. Bednarska-Pituła. Warszawa-Toruń 1994, s. 79.

${ }^{24}$ G. Labuda, Zadania i cele historii regionalnej $w$ systemie historiografii, „Rocznik Kaliski”, T. X, 1977, s. 20. 
wanie pojęcia „region historyczny” jest konieczne przed przystąpieniem do jakichkolwiek badań z zakresu historii regionalnej, bez bowiem wszechstronnego uzasadnienia, że mamy do czynienia z regionem historycznym nie powinniśmy podejmować decyzji opracowania naukowych dziejów jakiegokolwiek terenu ${ }^{25}$. Polemizował m.in. ze stanowiskiem K. Buczka w kwestii łączenia regionów historycznych $\mathrm{z}$ jednostkami administracji terytorialnej: Nie będzie więc na ogót regionem historycznym powiat czy nawet województwo, jeżeli jako catość nie charakteryzowaty się w rozwoju historycznym czymś odręb$n^{n} m^{26}$. Wyraźnie również odniósł się do zastosowania ustaleń geograficznej analizy regionalnej do potrzeb charakterystyki nad regionem historycznym. Zdaniem Topolskiego pojęcie regionu historycznego jest pojęciem znacznie bogatszym niż pojęcie regionu geograficznego, zwłaszcza że nie każdy region geograficzny jest jednocześnie regionem historycznym (i odwrotnie). Dlatego ustalenia geografów mogą mieć mniejsze lub większe znaczenie dla dyskusji historyków, pamiętając jednak zawsze, że elementy geograficzne będą stanowić jeden $\mathrm{z}$ wielu czynników opisujących region historyczny ${ }^{27}$.

Niewątpliwą zasługą J. Topolskiego było przede wszystkim sformułowanie pełnej definicji regionu historycznego, do której przez kolejne lata odwoływali się (i nadal to czynia) historycy zajmujący się problematyką regionalną. Warto jednak zwrócić uwagę, że stanowisko Topolskiego w tej kwestii ewoluowało w pewnym stopniu na przestrzeni kilkudziesięciu lat, a zwłaszcza po adaptacji do jego badań narratywistycznych nurtów filozofii historii. Już przy pierwszej prezentacji swojej koncepcji pod koniec lat 60. badacz ten zwrócił uwagę na złożoność regionu historycznego, nazywając go odnoszącym się do określonego terytorium skomplikowanym układem o określonej strukturze, w którym rolę elementu wyróżniającego odgrywają dzieje. Ponieważ przeszłość ma charakter wielowymiarowy, poprzez „dzieje” możemy rozumieć zarówno ich całokształt, jak i jakąś ich dziedzinę. Z tego też względu będziemy mieli do czynienia z różnymi, nazwijmy to „rodzajami” regionów historycznych, np. politycznymi regionami historycznymi, gospodarczymi regionami historycznymi (jeżeli uwzględnimy wybrany aspekt tych dziejów) lub też „integralnym regionem historycznym”, gdy uwzględnimy całość pro-

25 J. Topolski, Pojęcie regionu historycznego, [w:] Dzieje Wielkopolski, t. 1, Poznań 1969, s. 24-25.

26 Ibidem, s. 24.

27 Ibidem, s. 23-24. 
cesu dziejowego ${ }^{28}$. W koncepcji tej Topolski zawarł również swoje poglądy na temat struktury regionu historycznego, zapowiadając niejako późniejsze odniesienia do metodologii badań regionalnych. Po pierwsze, zwrócił uwagę na istnienie mniejszych regionów historycznych, które współtworzą większe jednostki („mikroukład”) rozległej struktury, jaką jest większy region historyczny. Po drugie, stwierdził, że o miejscu i znaczeniu danego regionu historycznego w tej większej strukturze decydują różne (i zmieniające się) czynniki, do których zaliczył m.in. jego osobliwości gospodarcze, społeczne, kulturalne, stosunki etniczne i charakter geograficzny. Jeżeli chcemy w pełni opisać region historyczny, musimy uwzględniać te czynniki, zarówno w ich różnorodności, jak i w wymiarze historycznym, czyli zmieniającym się w czasie ${ }^{29}$.

Przedstawioną powyżej koncepcję regionu historycznego Jerzy Topolski modyfikował i uzupełniał przez następne lata, włączając w szerszy zakres swoich zainteresowań metodologię historycznych badań regionalnych. W połowie lat 90. zaproponował m.in. potraktowanie regionu historycznego jako kategorii narracji historycznej. Aplikując bowiem do swoich rozważań elementy teorii narratywistycznej, skonstatował, że region historyczny jest konstrukcją badacza, a badacz ten, analizując (opisując) wspólną dla ludzi danego terenu historię, nadbudowywuje nad pewną rzeczywistość geograficzną - tkankę pojęcia regionu historycznego. Potwierdził, jak to było w latach 60., że kryterium zasadniczym dla funkcjonowania regionu historycznego jest przede wszystkim historia, wspólne bytowanie różne $w$ jakimś stopniu od takiegoż bytowania ludzi na innych terenach ${ }^{30}$. Na uwagę zasługuje wyróżnienie przez J. Topolskiego wśród czynników (kryteriów) współtworzących region historyczny nie tylko dziejów (wspólnej przeszłości) danego terytorium, ale podkreślenie także znaczenia elementów geograficznych, czy jak wcześniej pisał „charakteru geograficznego”, przy jednoczesnym niewymienianiu innych. Zastrzegł jednak wyraźnie różnicę w rozumieniu przez siebie pojęcia „rzeczywistości geograficznej” i „regionu geograficznego”, traktując ten ostatni jako konstrukcję (ustalenie) geografów. Jego zdaniem region historyczny bywa czasem powiązany z regionem wyróżnionym z punktu widzenia geograficznego, choć owo powiązanie nie jest dla funkcjonowania re-

28 Ibidem, s. 24.

29 Ibidem, s. 25.

${ }^{30} \mathrm{~J}$. Topolski, Jak się pisze i rozumie historię. Tajemnice narracji historycznej, Warszawa 1996, s. 145-150. 
gionu historycznego kryterium zasadniczym. Pojęcie „rzeczywistości geograficznej”, choć tego wprost nie sformułował, wydaje się rozumieć szerzej, jako element przestrzeni, w czym widać wcześniejsze sugestie H. Madurowicz-Urbańskiej.

Wystąpienie Jerzego Topolskiego na początku lat 70. wyraźnie zmieniło kierunek dyskusji nad delimitacją regionu historycznego, powodując m.in. odejście od poszukiwania tylko jednego kryterium regionalizacji historycznej. Kolejni badacze starali się najczęściej rozwijać koncepcję J. Topolskiego, zwłaszcza w odniesieniu do wskazanych przez niego tzw. elementów struktury regionu ${ }^{31}$. Jako pierwszy nawiązał do tej koncepcji Antoni Podraza przy okazji prowadzonych przez siebie badań nad dziejami Małopolski ${ }^{32}$. Jego zdaniem podziały administracyjne wprawdzie rzutowały na kształtowanie się regionów historycznych, ale nie stanowily jedynego czynnika regionotwórczego. Opowiadając się za tezą J. Topolskiego, że głównym (ale też nie jedynym!) kryterium charakteryzującym region są jego dzieje jako pewnej całości, wskazał jednocześnie na inne czynniki, również o charakterze historycznym, takie jak m.in. zawartość geograficzna danego terytorium, związi gospodarcze i kulturalne czy odrębności etniczne, które współdecydują o odrębności danego regionu historycznego ${ }^{33}$. Na początku lat 80. A. Podraza zaproponował również własną koncepcję tzw. wielkich regionów historycznych, obejmujących tereny kilku państw lub ich części. W jego rozumieniu tak postrzeganych regionów byłby np. podział Europy w średniowieczu na dwa wielkie regiony: zachodni (łaciński i katolicki) i wschodni (bizantyjski i ortodoksyjny), albo np. podział Europy nowożytnej pod względem gospodarczym na region zachodni, leżący na zachód od Łaby, i wschodni, położony na wschód od niej ${ }^{34}$.

Ciekawe stanowisko w sprawie delimitacji regionu historycznego zajął również Roman Wapiński w swoim wystąpieniu podczas posiedzenia Komisji Historii Regionalnej Zarządu Głównego Polskiego Towarzystwa Historycznego w Karpaczu w 1977 r., poświęconym problemom związanym

31 Idem, Wielkopolska jako region historyczny, s. 25.

32 A. Podraza, O potrzebie opracowania dziejów Małopolski, „Kwartalnik Historyczny”, R. XV, 1972, z. 2 (57), s. 161-175.

33 Ibidem, s. 167.

${ }^{34}$ A. Podraza, Wielkie regiony historyczne w Europie. Pojęcie i przydatność badawcza, [w:] „Sprawozdania z posiedzeń komisji naukowych PAN”, t. XXIII, 1979, z. 2, s. 308-310. 
z monografiami regionalnymi ${ }^{35}$. Podzielił on pogląd innych historyków, że „współczesne podziały administracyjne i polityczne” nie mogą służyć do „ujmowania dawniejszych epok", tego typu zabiegi określił nawet dobitnie jako "ahistoryczne” i wywołane często presją mecenatu wojewódzkiego lub powiatowego, a także nadmierną umownością pojęcia „region”. Wprawdzie docenił on wkład J. Topolskiego w konceptualizację tego pojęcia, ale uznał je za niewystarczające, ponieważ brak w nim cech odróżniających region od ojczyzny (terytorium państwowego) ${ }^{36}$. Sam zaproponował przyjęcie za podstawę regionalizacji historycznej socjologiczną koncepcję Stanisława Ossowskiego, który uważał, że region w sensie socjologicznym jest korelatem regionalnej zbiorowości. A zbiorowość regionalna to zbiorowość terytorialna, która ma w większym lub mniejszym stopniu poczucie swej odrębności, ale nie uważa się za naród ${ }^{37}$. Zdaniem R. Wapińskiego podejście Ossowskiego mogło w pełni zostać przyjęte także przez historyków. Dostrzegając bowiem rolę zjawisk historycznych w formowaniu się regionu w sensie socjologicznym, wprowadzał on bardzo przydatny w badaniach historycznych podział na dwa rodzaje regionów: mniejsze regiony, oparte na dawniejszej przeszłości i różnicach folklorystycznych, oraz duże regiony, jak np. Galicja, Kongresówka czy Poznańskie, których ludność zachowała poczucie odrębności wytworzone na skutek podziałów granicznych w czasach zaborów ${ }^{38}$.

Wśród innych propozycji określenia czynników regionotwórczych warto przywołać jeszcze stanowisko Władysława Rusińskiego, przedstawione na XIII Powszechnym Zjeździe Historyków Polskich w 1984 r. ${ }^{39}$ Uznał on bowiem, że w procesie kształtowania się regionów historycznych, rozumianych przez niego jako obszar o historycznie ukształtowanej specyfice kulturowej i gospodarczej, z ośrodkiem miejskim pełniącym funkcje jego „stolicy”, ważną rolę odgrywały stosunki rynkowe. Argumentował ten pogląd tym, że początki odrębności regionów, przejawiające się m.in. w kulturze, zwyczajach

35 Tekst tego wystąpienia, a także innych prelegentów oraz zapis dyskusji, zostały opublikowane w monograficznym numerze „Komunikatów Mazursko-Warmińskich”. R. Wapiński, Historia regionalna a narodowa, „Komunikaty Mazursko-Warmińskie”, 1978, nr 2, s. 155-169.

36 Ibidem, s. 157.

37 S. Ossowski, Zagadnienie więzi regionalnej i więzi narodowej na Ślasku Opolskim, [w:] idem, Dzieta, t. 3, Warszawa 1967, s. 252.

38 R. Wapiński, op. cit., s. 158.

39 W. Rusiński, Rola badań regionalnych w polskiej historiografii, [w:] Pamiętnik XIII Powszechnego Zjazdu Historyków Polskich. Poznań 6-9 września 1984 r. Część 1: Referaty plenarnesekcje, red. H. Izdebski, Wrocław 1986, s. 97-105. 
i obyczajach, przypadają w dużej mierze na okres rozwoju miast i rynków lokalnych. Jego zdaniem właśnie rynek sprzyjał kształtowaniu się świadomości regionalnej, co doprowadziło do wydzielenia się poszczególnych regionów ${ }^{40}$.

Dość radykalne stanowisko w sprawie delimitacji regionów, a tym samym kolejny zwrot $\mathrm{w}$ dyskusji na ten temat, zaproponował $\mathrm{w}$ połowie lat 80. Andrzej Wyrobisz ${ }^{41}$. Wprawdzie przyjął on definicję regionu historycznego, sformułowaną wcześniej przez J. Topolskiego, ale znacznie uzupełnił niektóre elementy tej koncepcji, m.in. związane $\mathrm{z}$ rozumieniem pojęcia regionu przez historyków. Zwrócił on przede wszystkim uwagę na trzy odmienne podejścia badaczy do tego pojęcia oraz na konsekwencje z tych podejść wynikające. Część historyków - zdaniem Wyrobisza - traktuje region historyczny jako narzędzie badawcze, co oznacza, że uznają oni podziały regionalne albo jako wytwór badacza, poczyniony np. w celu uporządkowania materiału, albo jako coś istniejącego realnie, co badacze próbują wykryć (ustalić). W pierwszym przypadku istotne jest przede wszystkim ścisłe sprecyzowanie kryteriów, które zostały użyte do podzielenia badanej przestrzeni, w drugim natomiast - przeprowadzenie odpowiednich badań, które pozwolą ustalić te rzeczywiste (istniejące) podziały regionalne (jakie one są, co jest kryterium ich wydzielenia). Dla innych badaczy natomiast region historyczny to przede wszystkim pole badawcze. Mniej ich wówczas interesują granice badanego regionu, a koncentrują się głównie na opisie i analizie wydarzeń, które wystąpiły na obszarze tego regionu. I wreszcie trzecia grupa badaczy, którzy pojmują region jako przedmiot badań. Jak uznał A. Wyrobisz, jest to najmniej liczna grupa. Zajmuje się ona poszukiwaniem wszelkiego rodzaju więzi społecznych, zależności gospodarczych, osobliwości ustrojowych, tradycji kulturowych spajających i współtworzących społeczności regionalne oraz na wyjaśnianiu powiązań zjawisk społecznych z określonym terenem, który można nazwać regionem historycznym ${ }^{42}$. On sam natomiast zaproponował, by regionu historycznego nie traktować wyłącznie jako pojęcia teoretycznego, lecz przede wszystkim jako realny wytwór procesu historycznego, by tym samym przestał być „polem obserwacji naukowej”, a stał się przedmiotem badań. Wskazał nawet pewne propozycje badawcze, jak np.

40 Ibidem, s. 98.

41 A. Wyrobisz, O pojmowaniu regionów historycznych $w$ nauce polskiej, „Kwartalnik Historyczny”, R. XCIII, 1986, nr 1, s. 133-148.

${ }^{42}$ Ibidem, s. 145. 
badania nad regionami gospodarczymi, czy historycznymi społecznościami regionalnymi, które - jego zdaniem - właśnie w ten sposób pozwalają region historyczny traktować ${ }^{43}$. W konsekwencji takiego sposobu ujęcia regionu historycznego uznał również, że nie można proponować jakiegoś uniwersalnego i ponadczasowego podziału kraju na regiony historyczne, ponieważ dla każdej epoki taki podziat musi być odmienny. Postulując ograniczenie badań z zakresu historii regionalnej do konkretnych okresów historycznych, a nie do całości dziejów Polski, nawiązał w pewnym sensie do koncepcji K. Buczka. Zdaniem A. Wyrobisza najciekawsze poznawczo byłoby ustalenie podziałów regionalnych, charakterystycznych dla poszczególnych epok, ponieważ dzięki temu moglibyśmy poznać procesy społeczne, gospodarcze i kulturowe właściwe dla tych epok ${ }^{44}$. Zaproponował ponadto, jak dotąd najobszerniejszy, zestaw czynników regionotwórczych, do których zaliczył: zwartość obszaru geograficznego, stosunki demograficzne, strukturę społeczną, odrębności etniczne, kulturowe i językowe, stan społecznej świadomości (w tym również świadomości historycznej), sieć komunikacyjną, specjalizację gospodarczą oraz istnienie (lub brak) więzi gospodarczych, a także istnienie ośrodka, wokół którego mogła następować krystalizacja regionu ${ }^{45}$.

W ostatnich latach dyskusja nad rozumieniem regionu historycznego nieco przygasła. W zasadzie nie pojawiła się żadna nowa propozycja jego zdefiniowania, a ci badacze, którzy podejmują szersze problemy, powiązane w jakimś stopniu z analizą tego pojęcia, odwołują się do ustaleń Jerzego Topolskiego (jak np. Andrzej Stępnik czy Rafał Stobiecki) ${ }^{46}$ lub ewentualnie uzupełniają niektóre elementy tej koncepcji, jak to było w przypadku wspominanego Andrzeja Wyrobisza. Kwestią definicji regionu historycznego nie zajęto także w 2005 roku, podczas poznańskiej konferencji poświęconej nowemu modelowi historycznych badań regionalnych, mimo iż w swej koncepcji programowej stanowiła ona próbę odniesienia się dotychczasowego dorobku historiografii regionalnej w Polsce ${ }^{47}$. Na konferencji tej natomiast

43 Ibidem, s. 146.

${ }^{4}$ Ibidem, s. 147.

45 Ibidem, s. 147-148.

46 Patrz m.in.: A. Stępnik, Główne kierunki w historiografii regionalnej i lokalnej, [w:] Kronikarz a historyk. Atuty i stabości regionalnej historiografi, red. J. Spyra, Wyd. Książnica Cieszyńska, Cieszyn 2008, s. 35-38 (publikacja ta dostępna jest tylko w wersji elektronicznej pod adresem: www.kc-cieszyn.pl; stan na grudzień 2010 r.) oraz R. Stobiecki, Historiografia regionalna. Nowa wizja dziejów czy nowa metoda?, [w:] ibidem, s. 11-33.

$47 \mathrm{Na}$ temat tej konferencji patrz: O nowy model historycznych badań regionalnych, red. 
zajęto się ponownie problemem delimitacji regionów historycznych, zwracając m.in. uwagę na ciaggle aktualny problem trudności w ustaleniu granic badanych regionów. Jak zauważano, choć wszyscy zdają sobie sprawę z tego, że granice te zmieniały się przez wieki, to jednak w konkretnych przypadkach niezwykle trudno określić zasięg terytorialny regionu, w skład którego na przestrzeni dziejów wchodziły różne ziemie, czasem będące w granicach innego regionu. Marek Czapliński zaproponował wówczas, jako sposób na wyjście z tych trudności, rozwiązanie, które przyjęli autorzy Historii Ślaska ${ }^{48}$, polegające na tym, że podstawą w określeniu granic badanego regionu powinny być współczesne granice województwa, przy jednoczesnym założeniu, że w badaniach uwzględniane będą również te ziemie, które kiedyś do tego regionu zaliczano i tylko w tych okresach, kiedy do regionu przynależały ${ }^{49}$. Propozycja Czaplińskiego, choć niestety nie wywołała na konferencji szerszej dyskusji na ten temat, to jednak zasygnalizowała kolejny kierunek, w którym najprawdopodobniej będą zmierzać dalsze rozważania nad delimitacją regionów historycznych (narzucony przede wszystkim praktyką badań regionalnych). W swej zasadniczej idei odwołuje się ona bowiem do znanej już w okresie międzywojennym (ale i wielokrotnie krytykowanej w czasach Polski Ludowej) koncepcji powiązania granic regionów ze współczesnymi (w danym okresie) podziałami administracyjnymi. $Z$ tą jednak różnicą, że granice te przyjmuje jako punkt wyjścia i dopuszcza ich „dynamiczne” traktowanie. Istotną w tym przypadku rolę odgrywa również zasada (zasady), na podstawie której dokonano aktualnie obowiązującego podziału administracyjnego, a także to, w jakim stopniu uwzględnione zostały w tym podziale różnice regionalne i czy utworzone województwa stanowią w jakimś stopniu regiony historyczne (zgodnie z definicją regionu historycznego).

Brak zgodności historyków co do kryteriów delimitacji regionu historycznego, a także występowanie obok siebie wielu, często odmiennych, propozycji regionalizacji historycznej spowodowały swego rodzaju dowolność w badaniach regionalnych i wywarły również piętno na edukacji regional-

K. A. Makowski. Poznań 2007 oraz T. Łaszkiewicz, P. Olstowski, Refleksje na marginesie poznańskiej konferencji o nowym modelu monografii miast i syntez historycznych, „Zapiski Historyczne”, T. LXXI, 2006, z. 2-3, s. 155-162.

48 Historia Ślaska, red. M. Czapliński, Wrocław 2002.

49 M. Czapliński, „Nowy model” czy „nowe modele”? Próba polemiki z niektórymi tezami Witolda Molika, [w:] O nowy model historycznych badań regionalnych, red. K. A. Makowski, Poznań 2007, s. 49-50. 
nej. Z nagromadzeniem terminologicznych ustaleń akademickich i wspomnianą różnorodnością stanowisk wśród historyków-badaczy środowisko dydaktyczne próbowało sobie radzić na różne sposoby. Zdarzały się zatem postawy radykalne, jak np. opinia wyrażona w 1957 r. przez Franciszka Persowskiego,

że dla celów szkolnych obojętną będzie rzeczą ścisłe określenie regionu. W wielu wypadkach określenie takie [czyli region - przyp. autorki] nasunie się samo pod kątem widzenia historyczno-administracyjnym, geograficznym czy nawet współcześnie administracyjnym. [...] Będą jednak regiony bez specyficznych cech wyróżniających i tu praktycznie można by się oprzeć na współczesnym podziale administracyjnym i ujmować jako region województwo ${ }^{50}$.

Zdecydowanie częściej jednak poprzestawano na ogólnikowym używaniu pojęcia region, nie precyzując dokładnie, jakie czynniki (kryteria) go wyróżniające należy przyjąć w praktyce.

Pierwszą, która wśród dydaktyków historii dostrzegła wątpliwości, jakie budziło pojęcie regionu i wskazała na brak jednoznacznych zasad delimitacji regionów historycznych, była Hanna Pohoska w latach 30. XX wieku. Jako praktyczne rozwiązanie proponowała wprowadzenie tzw. czynnika regionalnego (jak to określał ówczesny program nauczania) dwukierunkowo: jako ogólną znajomość wszystkich regionów etnograficznych Polski i ich przeszłości, a szczegółowo - jako pogłębioną znajomość przeszłości tylko własnego regionu. Wyraźnie przy tym rozdzieliła pojęcie dzielnicy historycznej (jak np. Mazowsze, Pomorze), w której istotnym kryterium wydzielenia powinna być rdzenna tradycja historyczna, od pojęć regionu etnograficznego, gospodarczego geograficznego, zwracając jednocześnie uwagę na możliwość pokrywania lub zazębiania się tych regionów w obrębie dzielnicy historycznej. ${ }^{51}$ Inne opracowania dydaktyczne $\mathrm{z}$ tego okresu w zasadzie nie wprowadzały niczego nowego, można nawet odnieść wrażenie, że środowisko dydaktyczne niejako zdawało się nie dostrzegać toczącej się równolegle wśród historyków dyskusji nad pojęciem regionu historycznego. Podob-

50 F. Persowski, Regionalizm w praktyce szkolnej, „Historia i Nauka o Konstytucji”, R. V, 1957, nr 6, s. 477.

51 H. Pohoska, Historia w szkole powszechnej. Wskazówki metodyczne zastosowane do nowego programu, Warszawa 1933, s. 112 i 115. 
nie przedstawiała się sytuacja po II wojnie światowej, kiedy to wzorem lat międzywojennych, koncentrowano się przede wszystkim na kwestiach metodycznych regionalizmu w nauczaniu historii i zajmowano się interpretacją wytycznych programowych, a zdecydowanie w mniejszym stopniu śledzono akademickie rozważania teoretyczne.

Za kolejną próbę wypracowania praktycznego rozumienia regionu historycznego, mogącego znaleźć zastosowanie w edukacji szkolnej, możemy uznać artykuł Tadeusza Słowikowskiego i Stanisława Wróbla, opublikowany w 1957 r. na łamach czasopisma metodycznego „Historia i Nauka o Konstytucji” ${ }^{2}$. Jego autorzy, próbując metodycznie zmierzyć się z problemem niejednoznaczności pojęcia regionu (w tym także historycznego), zaproponowali kompromisowe rozwiązanie na potrzeby praktyki szkolnej. Ich zdaniem trzeba było w sposób umowny ustalić, co nauczyciel miał rozumieć pod pojęciem regionu i, abstrahując od dawnych podziałów historycznych (choć ich nie eliminując), przyjąć, że

punktem wyjścia w określeniu regionu powinno być stwierdzenie skupiającej pod względem gospodarczym i kulturalnym roli jakieś miejscowości, przy jednoczesnym określeniu zasięgu tych wpływów w przeszłości, jak i współcześnie, przy czym nie bez znaczenia będą w tym wypadku połączenia komunikacyjne $e^{53}$.

W ten sposób decyzję o wytyczeniu zasięgu regionu, którym mieli się zajmować uczniowie na lekcjach historii, miałby podejmować sam nauczyciel, przyjmując stan obecny jako punkt odniesienia. Żeby jednak to ambitne założenie było możliwe, konieczne było - ich zdaniem - przełamanie oporu samych nauczycieli, zniwelowanie trudności obiektywnych (jak przeładowanie programów, brak odpowiedniego przygotowania nauczycieli, trudności w dostępie do źródeł historycznych), wreszcie - postęp w badaniach regionalnych i zorganizowanie życia naukowego ośrodków pozauniwersyteckich $^{54}$. Bardziej skrajne stanowisko w sprawie zasad delimitacji regionu na potrzeby praktyki szkolnej zaproponował w tym samym czasie wspominany powyżej Franciszek Persowski, przekonując, że wobec dyskusyjności pojęcia

52 T. Słowikowski, S. Wróbel, Jeszcze o regionalizmie w nauczaniu historii, „Historia i Nauka o Konstytucji”, R. V, 1957, nr 4/5, s. 262-276.

53 Ibidem, s. 267.

54 Ibidem, s. 268-269. 
regionu szkoła nie jest w stanie (ani też nie powinna) określać specyfiki danego regionu, pozostawiając tę kwestię rozważaniom naukowym. Dla ominięcia teoretycznych trudności w określaniu regionu proponował odwoływanie się do materiału źródłowego dotyczącego najbliższego terenu bez zwracania uwagi na to, czy spełnia on kryteria regionu, czy też nie ${ }^{55}$.

Szerzej problemem rozumienia pojęcia regionu historycznego oraz zasadami jego delimitacji środowisko dydaktyczne zajęło się dopiero w drugiej połowie lat 70. XX wieku. Ukazał się wówczas zbiór rozpraw i artykułów pod redakcją Józefa Półćwiartka i Alojzego Zieleckiego, w którym po raz pierwszy podjęto kompleksową refleksję nad metodologią i problematyką badawczą historii regionalnej z punktu widzenia edukacji szkolnej. Odwołując się głównie do definicji regionu Tadeusza Słowikowskiego, a pomijając znaną już wówczas dyskusję na ten temat jaka toczyła się w środowisku historyków (!), J. Półćwiartek i A. Zielecki ujmowali pojęcie regionu historycznego bardzo wąsko, akcentując nie tyle wspólną przeszłość danego terytorium, co istnienie jakiegoś centrum (ośrodek miejski), wytwarzającego określone powiązania z najbliższą przestrzenią. Ich zdaniem region to

obszar podobny rynkowi lokalnemu, który występował i występuje na pewnym terytorium, z wykształconym w przeszłości ośrodkiem miejskim integrującym gospodarkę, społeczeństwo i kulturę tej przestrzeni, przed którym istnieją perspektywy dalszego rozwoju, a wiedza o tym regionie będzie wyzwalać inicjatywę społeczną, wytwarzać przywiązanie do stron rodzinnych mieszkańców ${ }^{56}$.

Co ciekawe, za istotne kryterium wyróżnienia (delimitacji) regionu uznali czynniki trudne do weryfikacji naukowej, chociażby ze względu na ich prognozowany charakter, jak np. istnienie perspektyw rozwojowych tego terenu, wyzwalanie w przyszłości aktywności społecznej czy wytwarzanie (również w przyszłości) więzi emocjonalnej.

Po raz kolejny, i jak do tej pory ostatni, do problemu regionu historycznego wrócono kilkadziesiąt lat później, kiedy to w 1999 roku po wprowadzeniu edukacji regionalnej do szkół ponownie sprawą kluczową stało się ustalenie, jak należy ten obszar rozumieć i na podstawie jakich kryte-

55 F. Persowski, op. cit., s. 477.

${ }^{56}$ Metodologiczne i dydaktyczne problemy historii regionalnej, red. J. Półćwiartek i A. Zielecki, Rzeszów 1977, s. 11-12. 
riów można go określać. Głos wówczas zabrał wspominany powyżej Józef Półćwiartek, który w swoim artykule zwrócił uwagę na niejednoznaczne i niekompletne użycie pojęcia regionu w dokumentach ministerialnych (nie precyzowały one bliżej zakresu terytorialnego i merytorycznego regionu, rozumiejąc to pojęcie jako terytorium z zamieszkującą je ludnością, które ma wspólne właściwości kulturowe i przeszłość historyczną, nie określając jednocześnie, jak duży terytorialnie ma być region i jakie determinanty powinny go określać) ${ }^{57}$. Wyraził przy tym obawę (którą do tej pory niewielu dydaktyków wypowiadało głośno, choć większość miała tego świadomość!), że trudno będzie nauczycielom poradzić sobie ze zrozumieniem pojęcia regionu, jeżeli wśród historyków-profesjonalistów istnieje tak duża rozbieżność stanowisk, a wytyczne programowe zdają się tej kwestii nie zauważać. Co ciekawe, analizując pojęcie regionu w publikacjach innych badaczy, J. Półćwiartek ze swej strony zauważył, że region duży zawiera w sobie zwykle hierarchię mniejszych obszarowo regionów, które w większym stopniu niejednokrotnie były odporne na zmienne losy historyczne. Oba rodzaje regionów ulegały jednak ewolucji w procesie historycznym (zmieniał się ich zasięg terytorialny, znaczenie i tożsamość), dlatego można mówić - zdaniem J. Półćwiartka o zjawisku „pulsowania regionów”, uwzględniającym nie tylko tę wspomnianą hierarchię, ale także ich zmienność na przestrzeni wieków ${ }^{58}$. Takie właśnie zróżnicowanie pojęcia regionu: od najbliższej miejscowości, przez tzw. małą ojczyznę (region) do prowincji (makroregionu, jak np. Małopolska) oraz zachowanie jego zmienności terytorialnej czasów przeszłych uważał on za najlepsze rozwiązanie praktyczne i jednocześnie gwarancję rozumienia przez nauczycieli programu ministerialnego oraz celów jego realizacji ${ }^{59}$.

Brak jednoznacznego przełożenia dyskusji, toczącej się w środowisku historycznym nad sposobem rozumienia i rozgraniczenia regionu historycznego, do refleksji podejmowanej nad tym problemem wśród dydaktyków historii, konsekwentnie oddziaływało (w pewnym zakresie oczywiście) na edukację szkolną. Określenie zasad delimitacji regionu historycznego miało bowiem znaczenie przede wszystkim praktyczne, nie tylko przy podejmowaniu badań regionalnych, ale także w szeroko rozumianej edukacji regionalnej

57 J. Półćwiartek, Dziedzictwo kulturowe $w$ regionie $w$ ścieżce międzyprzedmiotowej, [w:] Edukacja historyczna w reformowanej szkole. Propozycje rozwiąań praktycznych, red. A. Zielecki, Seria: Nowa szkoła, t. 2, Kraków 2000, s. 74-76.

58 Ibidem, s. 76.

59 Ibidem, s. 80. 
- nauczyciel musiał przecież wiedzieć, jakie obszary są regionami historycznymi lub jakie możemy uznać (na podstawie jakich kryteriów) za takowe. Jak można było zauważyć, środowisko dydaktyczne, będące niejako naturalnym „przekaźnikiem” akademickich ustaleń do praktyki szkolnej, jedynie $\mathrm{w}$ ograniczonym zakresie udzielało nauczycielom wsparcia w rozstrzyganiu dylematów definicyjnych regionalistyki historycznej i wynikających z nich rozstrzygnięć metodycznych. Zasadniczym zatem punktem odniesienia dla podejmowanych w szkole działań edukacyjnych pozostawały wytyczne ministerialne i programy nauczania, które zawierały mniej lub bardziej konkretne propozycje rozumienia regionu historycznego na potrzeby pracy z uczniem.

Mniej więcej do początku lat 30. XX wieku, kiedy to nawet w środowisku historyków nie dyskutowano jeszcze o definicji regionu historycznego i nie rozróżniano historii lokalnej od historii regionalnej, również w programach nauczania pojęcie regionu pojawiało się stosunkowo rzadko. Zdecydowanie częściej odwoływano się do przykładów z historii ówczesnych gmin lub powiatów ucznia, które służyły jako egzemplifikacja pozwalająca lepiej zrozumieć omawiane zagadnienia, ale także jako element wychowania narodowego i patriotycznego ${ }^{60}$. Te pierwsze programy wyraźnie wprowadzały rozróżnienie na miejsce rodzinne, naszą miejscowość i najbliższą okolicę, dopuszczając w uzasadnionych przypadkach odnoszenie wymienionych treści do różnych zasięgów terytorialnych najbliższego środowiska ucznia ${ }^{61}$. Praktycznym sposobem wprowadzania historii regionalnej, choć nie używano wtedy takiego określenia, było odwoływanie się do przeszłości wybranych miast w Polsce, m.in. Gniezna, Poznania, Krakowa, Warszawy, Lublina, Częstochowy, Wilna, Lwowa, Sandomierza i Kazimierza nad Wisłą. Co ważne, każde z tych miast reprezentowało przy tym inną część kraju i różne epoki historyczne, w których przeżywały one swoją świetność. Uczniowie poznawali je przez pryzmat ważnych wydarzeń z nimi związanych, zabytków, pomników i muzeów, jakie się w nich znajdują, oraz sławnych osób, które urodziły się w tych miastach lub z nimi związały swoje losy. Zgłębiając dzieje wybranych miast polskich i ich współczesny wygląd odbywali oni niejako specyficzną (wirtualna) wycieczkę krajoznawczą po Polsce. Ważna przy tym

${ }^{60}$ Program szkoty powszechnej jednoklasowej czterooddziałowej i dwuklasowej cztero- i pięciooddziałowej. Cz. VII. Historia, Warszawa 1918, s. 5-6.

${ }^{61}$ Ibidem, s. 22 oraz Program nauki w szkołach powszechnych siedmioklasowych. Historia, Warszawa 1920, s. 9; Program gimnazjum państwowego. Gimnazjum niższe. Język polski, historia, języki nowożytne, Warszawa 1919, s. 27. 
była nie tylko wiedza o miastach sławnych i znanych z kart podręcznika, często znacznie oddalonych od miejsca zamieszkania ucznia, ale także istotna była znajomość najbliższej okolicy i miejsca, z którym się uczeń identyfikował w największym stopniu. Dlatego, oprócz treści krajoznawczych, umieszczono w programie również zagadnienia związane z historią lokalną, niejako nie podejmując wprost kwestii regionów historycznych i trudności wynikających z ich wyodrębnienia.

Jednoznaczne rozróżnienie w programach nauczania sposobu i zakresu odwoływania się do historii lokalnej i oddzielnie do historii regionu (regionalnej), a tym samym do rozumienia pojęcia regionu historycznego, wprowadziła dopiero w latach 30. XX wieku tzw. reforma Jędrzejewicza. Historia lokalna, traktowana jako element opisujący środowisko ucznia pojawiała się wówczas w trzech zakresach: jako forma zaznajamiania ucznia z zabytkami historycznymi na przykładzie najbliższej okolicy, jako powiązanie dziejów danej miejscowości z odpowiednimi treściami ogólnego programu historii, i wreszcie jako obserwacja przejawów życia politycznego, społeczno-gospodarczego i kulturalnego w najbliższym środowisku. Natomiast na historię regionalną patrzono przez pryzmat poznawania specyficznych cech własnego regionu, dlatego zalecano w odpowiednich partiach materiału nawiązywać do zagadnień regionalnych i stopniowo budować pełny obraz jego przeszłości. Region rozumiano przy tym jako terytorium odpowiadające dzielnicy historycznej lub terenowi zamieszkałemu przez daną mniejszość narodową. W obu przypadkach: historii lokalnej - opisującej środowisko i historii regionalnej - opisującej region, kładziono nacisk nie na wskazywanie różnic, mogących pogłębiać istniejące podziały, lecz podkreślano związki łączące je z całością państwa. Wyjaśniając, iż w ten sposób chodziło o doprowadzenie do: „zrozumienia, że wartości dorobku kulturalnego poszczególnych regionów i narodowości nie są elementami, które rywalizują ze sobą i nawzajem się zwalczają, lecz przeciwnie, że winny one współdziałać w wytwarzaniu wspólnej kultury Państwa Polskiego"62.

Po II wojnie światowej, w sytuacji gdy problematyka regionalna praktycznie nie była obecna (lub tylko w ograniczonym zakresie) w programach nauczania, kwestia rozumienia i wydzielania regionów historycznych straciła nieco na znaczeniu. Użyteczność edukacji historycznej powiązanej z ów-

${ }^{62}$ Program nauki w gimnazjach państwowych z polskim językiem nauczania (tymczasowy), Lwów 1934, s. 256-257. Patrz również: Program nauki (tymczasowy) w państwowym gimnazjum ogólnokształcącym z polskim językiem nauczania, wydanie drugie, Lwów 1937, s. 295-296. 
czesną sytuacją polityczną rozumiano przede wszystkim jako bliższe powiązanie szkoły z jej środowiskiem, krzewienie umiłowania stron rodzinnych oraz wywoływanie zainteresowania pracą dla dobra bliższej i dalszej okolicy, zawsze jednak z zaznaczeniem, że jest to etap szerszego procesu nastawionego na kształcenie miłości do ojczyzny i pożądanych postaw obywatelskich ${ }^{63}$. W żadnym z obowiązujących do połowy lat 70. programie nauczania nie ujęto w ramach obowiązkowych treści kształcenia zagadnień z zakresu historii lokalnej lub historii regionalnej. W całej bowiem koncepcji nauczania historii koncentrowano się wyraźnie na dziejach Polski i historii powszechnej, a to w pewnym stopniu wykluczało odniesienia do przeszłości najbliższej okolicy czy regionu. Elementy historii lokalnej i regionalnej dopuszczono jedynie jako uzupełnienie zasadniczego kursu historii i to na ściśle określonych zasadach. W pierwszym cyklu tematycznym były to „niektóre fakty i zdarzenia historyczne związane z daną miejscowością lub okolicą, wiążące się z odpowiednim tematem”" natomiast w kursie licealnym „historia własnego rejonu" "65. Uważano, że w klasach początkowych istotne jest poznawanie przeszłości Polski na przykładach zabytków znajdujących się w najbliższej okolicy ucznia, zgodnie z zasadą nawiązywania do przeżyć dzieci i wydarzeń z kręgu ich najbliższego otoczenia, z kolei w szkole średniej znajomość dziejów własnego rejonu (celowo nie używano określenia region!) miała ułatwić uczniom zrozumienie procesu dziejowego i udziału poszczególnych rejonów w życiu całości kraju ${ }^{66}$.

Możliwie szerokie wykorzystanie historii lokalnej i regionalnej, a tym samym bezpośrednie odniesienia do regionu historycznego, zawierał dopiero program dziesięcioletniej szkoły średniej, wprowadzony w drugiej połowie lat $70 .{ }^{67}$ Zwracano w nim jednak szczególną uwagę na zachowanie właściwych proporcje tematyki regionalnej w odniesieniu do dziejów ojczystych i powszechnych, a także podkreślano, by pamiętać o celu, jaki te zagadnienia mają osiągnąć. Wyraźnie bowiem zostało określone, że poznanie i wiązanie historii lokalnej i regionalnej z całością dziejów Polski „winno doprowadzić

63 Program nauczania w szkole podstawowej, Warszawa 1959, s. 9, 23 oraz 264.

${ }^{64}$ Program nauczania $w$ kl. I-IV szkoty ogólnokształcącej, Warszawa 1956, s. 68.

${ }^{65}$ Program nauki w 11-letniej szkole ogólnoksztatcacej, Projekt. Historia, Warszawa 1949, s. 173.

${ }^{66}$ Program nauczania $w$ kl. I-IV szkoły ogólnokształcącej, s. 67; Program nauki w 11-letniej szkole ogólnoksztatcacej. Projekt, s. 172; Program nauczania w szkole podstawowej, s. 27.

${ }_{77}$ Program dziesięcioletniej szkoty średniej. Historia, Warszawa 1976, s. 71-72. 
młodzież, z jednej strony, do pogłębienia więzi uczuciowych z regionem, z drugiej zaś - poczucia ścisłej łączności regionu z resztą kraju"68. Proponowano także, aby realizację tego elementu programu pozostawić całkowicie nauczycielowi, sugerując mu jedynie maksymalne związanie dziejów lokalnych z ogólną historią Polski. Co ważne, choć oficjalnie używano w programie pojęć „historia lokalna” i „historia regionalna”, a także wspominano o relacjach ucznia z regionem, to jednak w praktyce następowała redukcja tego związku do powiązań z najbliższym środowiskiem i historią lokalną, koncentrując się na przykładach i wskazówkach powiązanych właśnie z tym wymiarem lokalnym. O tym, jak wiązać historię Polski z historią regionu, nauczyciel nie miał szansy dowiedzieć się z programu, ponieważ oprócz ogólnych zaleceń w tej kwestii - uwag szczegółowych nie zamieszczono i tym samym nie wyjaśniono, co dokładnie należało rozumieć pod pojęciem regio$\mathrm{nu}^{69}$. Niezaprzeczalną jednak zasługą tego programu była nobilitacja historii lokalnej i regionalnej, nie tylko rozróżniono te dwa pojęcia, ale podkreślono także ich znaczenie w historii jako dziedzinie wiedzy, obok historii Polski czy historii powszechnej. I w tym sensie właśnie można zaobserwować tu wyraźny wpływ rozwijających się wówczas równolegle historycznych badań regionalnych oraz dyskusji, jaka toczyła się na ten temat w środowisku naukowym.

Po 1989 roku zakres tematyki regionalnej w programach nauczania historii zaczął stopniowo ulegać rozszerzeniu, a tym samym częściej zaczęto używać pojęcia „region historyczny” i więcej uwagi poświęcać jego obecności w podstawowym kursie historii. Między innymi w wydaniu programu nauczania dla zasadniczej szkoły zawodowej z 1990 r. dodano do kilku obligatoryjnych zagadnień z dziejów Polski tematy odnoszące się bezpośrednio do historii regionalnej, jak np. „Mój region w dobie powstań” (przy powstaniach narodowowyzwoleńczych w XIX wieku), „Mój region w dobie II Rzeczypospolitej”, „Mój region we wrześniu 1939 r.”, „Okupacja i ruch oporu w moim regionie” (przy omawianiu II wojny światowej) ${ }^{70}$. Przewidziano także jeden z tematów powtórzeniowych poświęcony historii miasta i regionu po II wojnie światowej ${ }^{71}$. Poza tymi obligatoryjnymi zagadnieniami zalecano ponadto, by niektóre tematy z historii Polski, jak np. „Kształtowa-

\footnotetext{
68 Ibidem, s. 72.

${ }^{69}$ Ibidem, s. 71-72.

70 Program zasadniczej szkoły zawodowej. Historia, Warszawa 1990, s. 7, 9 i 10.

${ }^{71}$ Ibidem, s. 15.
} 
nie granic Polski po I wojnie światowej” lub dzieje społeczeństwa polskiego w czasie II wojny światowej, uszczegóławiać w zależności od regionu, w którym znajduje się szkoła lub w całości omawiać na podstawie historii regionu, uwzględniając losy najbliższego otoczenia ucznia ${ }^{72}$. Niestety temu zwiększonemu zainteresowaniu historią regionu nie towarzyszyła pogłębiona refleksja nad możliwościami jego zdefiniowania lub przynajmniej kryteriów wydzielenia na potrzeby praktyki szkolnej. Ewentualne trudności z tego wynikające starano się rozwiązywać poprzez udzielanie nauczycielom wskazówek do konkretnych tematów, wyjaśniając na przykładach, jak należało rozłożyć akcenty w szkołach znajdujących się w różnych części Polski. I tak pisano m.in., że: „powstanie listopadowe będzie się omawiać szerzej w rejonie Warszawy, a powstanie styczniowe - na Podlasiu i Kielecczyźnie. Nauczyciele ziemi krakowskiej na tej samej lekcji omówią powstanie roku 1846 (nie zapominając kilka lekcji wcześniej zwrócić uwagi na miejscowości związane z powstaniem kościuszkowskim). Wiosna Ludów skonkretyzuje się przede wszystkim w Wielkopolsce"73. Jak można zauważyć, pojęcie regionu rozumiano w tym wypadku bardzo różnorodnie, zarówno w odniesieniu do dawnych regionów historycznych, jak np. Wielkopolska, ale także w wąskim zakresie - jako ziemia krakowska czy rejon Warszawy.

Niewiele niestety w tym względzie zmieniła reforma systemu oświaty w 1999 roku, o czym pisał wspominany wcześniej Józef Półćwiartek, kiedy to wprowadzono edukację regionalną jako obligatoryjną ścieżkę międzyprzedmiotową. Choć oficjalne dokumenty ministerialne często używały pojęcia „region”, to jednak nadal nie precyzowano w nich, jak należy je rozumieć i jakie w praktyce przyjąć zasady jego wydzielania. Ponieważ zakładano, że dzięki edukacji regionalnej zwróci się uwagę młodego człowieka na potrzebę ochrony regionalnego dziedzictwa kulturowego i uświadomi jego wartość, możemy przypuszczać, że region utożsamiano przede wszystkim $\mathrm{z}$ regionem kulturowym ${ }^{74}$, ale nie było to kryterium jedyne, ponieważ przy okazji uwzględniano także kryteria geograficzne, historyczne, językowe czy gospodarcze $^{75}$. Stąd zapewne wynikał fakt, że w programach autorskich, od-

72 Ibidem, s. 14.

73 Ibidem, s. 14.

${ }^{74}$ Ministerstwo Edukacji Narodowej o edukacji regionalnej-dziedzictwie kulturowym w regionie, Seria: „Biblioteczka reformy”, z. 24, s. 4.

75 Rozporzadzenie Ministra Edukacji Narodowej z dnia 15 lutego 1999 r. w sprawie podstawy programowej kształcenia ogólnego dla sześcioletnich szkót podstawowych i gimnazjów, „Dziennik 
noszących się do konkretnych regionów, panowała duża rozbieżność w rozumieniu tego pojęcia. Ponownie pojawiły się pogramy nauczania, używające pojęcia regionu w odniesieniu do dawnych regionów historycznych, jak np. Mazowsze $^{76}$, Małopolska ${ }^{77}$ czy Warmia i Mazury ${ }^{78}$, przy jednoczesnej obecności programów odwołujących się do dawnych lub współczesnych podziałów administracyjnych, np. region lubelski ${ }^{79}$ czy region świętokrzyskii ${ }^{80}$, do kryteriów geograficznych, np. region „Ujście Warty”" a także tworzące zupełnie nowe zakresy terytorialne regionu skoncentrowanego wokół wybranego ośrodka, np. ziemia tarnogórska ${ }^{82}$.

Przedstawiony powyżej przykład przenikania ustaleń teoretycznych historyków do refleksji dydaktycznej, a w konsekwencji także do edukacji szkolnej, potwierdził - w moim przekonaniu - jak niezmiernie złożony może być proces łączenia teorii z praktyką, jeżeli w przypadku tak rozlegle podejmowanego na przestrzeni wielu lat problemu definicji regionu historycznego nie udało się w zasadzie w sposób trwały zastosować w edukacji szkolnej żadnej propozycji zgłoszonej przez historyków-badaczy. Tym więk-

Ustaw Rzeczypospolitej Polskiej”, 1999, nr 14, poz. 129, s. 600 i 618 oraz Rozporzadzenie Ministra Edukacji Narodowej i Sportu z dnia 26 lutego 2002 r. w sprawie podstawy programowej wychowania przedszkolnego oraz ksztatcenia ogólnego w poszczególnych typach szkót, „Dziennik Ustaw Rzeczypospolitej Polskiej”, 2002, nr 51, poz. 458, s. 70-71.

${ }^{76}$ E. Bąk, U. Biskup, H. Friedel, Mazowsze - moja mała ojczyzna. Edukacja regionalna dziedzictwo kulturowe $w$ regionie. Program nauczania dla liceum ogólnokształcacego, liceum profilowanego i technikum, Kielce 2002.

77 W. Srokosz, M. K. Szmigiel, Edukacja regionalna dziedzictwo kulturowe w regionie. Matopolska ( $w$ granicach administracyjnych województwa małopolskiego). Program nauczania ścieżki edukacyjnej dla liceum ogólnoksztatcącego, liceum profilowanego i technikum, Toruń 2002.

78 R. Kirzeniewska, E. Świtalski, Edukacja regionalna. Dziedzictwo kulturowe Warmii i Mazur. Program ścieżki edukacyjnej dla szkoły podstawowej i gimnazjum, Toruń 2003.

${ }_{79}$ M. Bartoszewska, Lubelskie. Edukacja regionalna - dziedzictwo w regionie. Program ścieżki edukacyjnej w szkole podstawowej II etap edukacyjny: klasy IV-VI, Kielce 2001.

${ }^{80}$ J. Kuklińska, J. Osiecki, Świętokrzyskie - skarby Ziemi, serce Polski. Dziedzictwo kulturowe $w$ regionie. Programy nauczania dla szkoty podstawowej (klasy IV-VI) i gimnazjum, Kielce 2001 .

${ }^{81}$ I. Engel, M. Maksymczak, E. Miotk, Edukacja regionalna. Dziedzictwo kulturowe w regionie „Ujście Warty”. Program nauczania dla gimnazjum, Raszyn 2001.

82 J. Stomska, E. Susek, Edukacja regionalna dziedzictwo kulturowe w regionie (ziemia tarnogórska). Program dla liceum i technikum, Tarnowskie Góry 2005. 
szego zatem znaczenia nabiera, przywołana na początku niniejszego tekstu, funkcja humanistyczna dydaktyki historii, wymagająca od zaangażowanych w nią osób nie tylko stałego i systematycznego śledzenia dyskursu metodologicznego czy historiograficznego, zapoznawania się z najnowszymi ustaleniami nauki historycznej, ale przede wszystkim opracowywania na bazie tych inspiracji konkretnych rozwiązań metodycznych, odpowiadających realnym potrzebom praktyki szkolnej.

\section{Historical regions in historiography, history didactics and school-level education. Outline of positions and delimitation proposals Summary}

The first discussions on the definition of a historical region date back to the beginning of the interwar period. It was when the regional movement and the scientific circles noticed the need to additionally specify the basic category, so far used for regional research and across various forms of popularization of regional history. Some circles, at certain times, would understand the interest in historical regions differently. Regionalists engaged in organizational activities and would pay less attention to the issue of precise definition of borders and criteria for distinguishing regions. For historians researching regional history, the question of what historical regions were was of primary importance, as was consequently the adoption of tolerably unambiguous rules for delimitation of such regions. A similar situation could be observed across education circles - a teacher simply had to know what areas were actually historical regions and what criteria had to be used to distinguish them. Unfortunately, historians could not agree on the criteria for delimitation of historical regions and there were numerous competing proposals for historical regionalization. This led to a degree of freedom in regional research and had impact on regional education. The fundamental point of reference for educational activities across schools consisted mainly of ministerial guidelines and curricula that contained more or less specific proposals of understanding the idea of a historical region for schooling purposes. 